\title{
FINANCING CRAFT ENTERPRISES ASSOCIATED IN THE POLISH CRAFT ASSOCIATION
}

\author{
Joachim Foltys, Grażyna Dębicka-Ozorkiewicz, \\ Jolanta B. Królczyk, Vladimír Hiadlovský
}

\section{Introduction}

Small and medium enterprises (SME) sector has a key role in economic growth, employment and poverty alleviation [1], [4], [17]. In Europe is about 20 million SME and they play an important role in the European economy. These are mostly micro-enterprises and in 2012 employed approximately 86.8 million people. This represents $66.5 \%$ of all European jobs for that year. Almost 5.1 million enterprises operate in the manufacturing and the construction sectors; of these, 99.6\% are SMEs [9], [10]. Beck et al. [2], [3], [8] presented a positive relationship between the share of SMEs in manufacturing and gross domestic product (GDP) per capita growth.

According to Central Statistical Office of Poland (CSO) data, SME sector enterprises operating in Poland generate almost three fourth of Polish GDP. Result at a level of $71.8 \%$ in 2011 , after a small drop in share in 2010 , can mean a return to an upwards trend observed during the years 2006-2009. If we look at the enterprises' GDP share structure, it turns out that SME generate every second zloty $(47.3 \%)$, including the smallest enterprises every third $(29.4 \%)$. Medium entities' share is three times smaller $(10.1 \%)$ than the one of micro enterprises, whereas, in case of small enterprises - almost four times (7.8\%). In 2011 , in comparison with 2010 , the share of big companies in creating enterprises' GDP increased, whereas, the one of micro and medium enterprises - dropped, and in case of small ones - remained at a similar level [22].

The aforementioned results of the SME sector enterprises' influence, including micro enterprises, on the structure and level of Polish GDP, constitute grounds for detailed research in various areas of its functioning.

According to the CSO data, one can state that in majority (estimated level of $90 \%$ ), craft enterprises remain micro ones. Micro and craft (-type) enterprises in Europe are not only the main source of job creation in the EU, but they are active in many rather traditional professions that are essential for the prosperity and wellbeing of both urban and rural areas [6]. In compliance with the definition, craft is an independent business activity on a small scale, of a production - service character, conducted to the benefit of the workshop's owner and with his personal work input [13]. Craft enterprises can be also defined as a unique form of small and medium-sized enterprise (SME) and represent an combination between the manufacture of products and the fulfilment of artistic vision [30].

In comparison with the meaning of the notion "craft" binding until the end of 1972, provisions of the industrial law of 1927 extended its generic scope that at that time covered some types of service and production activities, until then not considered as craft. In compliance with the industrial law, craft would refer only to these types of activities that have been enumerated in the list of crafts [11]. Article 1 of the Act of 8 June 1972 on performance and organization of craft that entered into life as of 1 January 1973, defined craft as professional performance of production and service economic activities by natural persons, on their behalf [13].

The definition of the craft in accordance with the Act on performing and organizing craft of 1972 [13] includes an element stating that craft is performed by natural persons, thus, it requires personal work of a craftsman. However, this provision did not exclude employing in limited scope contract employees, if it resulted from economic conditions or requirements of service or production processes. The principle of personal performance of the craft resulted in limiting the possibility to perform craft by registered partnerships, limited liability companies and public limited companies constituted by legal persons acting pursuant to 
the provisions of commercial code. Companies of this type conducting craft activity as of the act on performance and organization of craft of 1972 entered into life could have been run in the hitherto prevailing form not longer than until the end of 1974. The provisions of the act did not limit the possibility to perform craft together by two or more craftsmen, who set up a company in compliance with the provisions of the civil code [12]. Craftsmen, who intended to run craft activity together had to possess license to perform craft as well as professional qualifications if these were required with regard to a particular type of craft.

During the process of political-economic changes in 1989, also legal regulations concerning craft were passed. Article 2.1. of the act of 22 March 1989 on craft [14] defines the notion of craft with the following words: "craft means professional performance of economic activity by a natural person or company's partners with qualified own work input, on their own behalf and to their benefit with employment of up to 50 employees". A craftsman is a person performing given economic activity. This act similarly as the previous one, does not define trade and transport activities, hotel services, services performed within liberal professions, medical services (with an exception of orthotic services) as well as production and service activities performed by visual artists and photographers as craft. The majority of these craft companies are family micro and small enterprises. As of today, there are 121 craft professions, in which qualifications can be confirmed at a level of apprentice and master before examination committees of craft chambers. The list of these professions is subject to changes, since, as a result of technical and technological development, new professions are continuously being created. Some professions are so specific that they are performed only in particular regions of the country, for example, professions such as: young shepherd, shepherd, fish processing worker or amber processing worker.

Researchers conducted all over the world and in our country proved that in the market economy, small and medium enterprises constitute one of fundaments of local and global economy constituting a significant group of its enterprises (level of approximately 90\%). Their establishment, development and functioning has a significant meaning for the development of local, regional, country and foreign markets as well as on the global market. It should be also added that development on the global market primarily constitutes a dynamic development of ICT technologies and thus, virtualization of their functioning. Craft enterprises typically have insufficient resources, inadequate access to specialised expertise and limited opportunities to make an impact on the marketplace [30]. One of the way to improve the competitive position of craft enterprises is by forming networks, cooperation, clusters [26], [30] and strengthening by innovation [26]. Innovation is nowadays a key factor for entrepreneurial activity [16], [28]. Innovation performance is higher in SMEs that are proactive in strengthening their relationships with innovative suppliers, users, and customers. Moreover SMEs will have better new product development results if they improve their relationships with laboratories and research institutes [19]. R\&D is no doubt a major resource for innovation. Innovation is progressively seen by analysts as an "interactive" and "distributed" process [29]. An increasing number of studies [7], [18], [20], [21], [25], [32] show that firms must increase their number of interactions with other market base actors (i.e., customers and suppliers) or research institutions (i.e., universities and research centers).

\section{Tools, Instruments and Conceptions of Financing Activity of Craft Enterprises}

Selection and availability of relevant forms of financing activity of craft enterprises constitutes an incredibly important aspect in their development process. Effective implementation of financing instruments optimal for particular types of craft enterprises determines their longterm position on particular national and foreign markets. Each sector has own characteristics (e.g. regarding product, technology, processes, relations with environment and others) which is reflected in types and manners of implementing tools and instruments for financing.

This article is aimed at identifying tools, instruments and conceptions for financing craft enterprises functioning on the Polish market. A supplementary aim of the study is to identify barriers in using tools and instruments and selected conceptions in financing functioning of craft enterprises. For the purposes of this study, financing of craft enterprises' functioning within 
investment as well as operational sphere was defined.

Taking into consideration only the investment activity of SME sector, in compliance with the Report on its condition of 2013 [22], one can quote, as follows:

1. An increase in investment outlay in SME sector in 2011, in comparison with previous year amounted to $13 \%$ and obtained over PLN 80 billion (approximately EUR 20.0 billion), with PLN 161 billion (approximately EUR 41.0 billion) of investment of whole enterprises sector.

2. An increase in outputs in SME sector on a company in 2011, in comparison with previous year by PLN 4 thousand (up to the level of PLN 45.4 thousand).

3. An increase in investment outlays in 2011 , in: micro - by $13.8 \%$, medium - by $14.1 \%$ and big enterprises - by $13.9 \%$, in comparison with 2010.

4. $50 \%$ of investment outlays are born by the SME and $50 \%$ - by big enterprises.

5. Investment outputs of service companies - 35\% and industrial companies - $31 \%$ in total SME sector outputs constitute $2 / 3$ of SME sector outputs.

6. Own resources constitute financing source of $2 / 3$ investments realized by the SME sector in 2011.

7. In 2010, enterprises in Poland increased outputs on fixed assets by approximately EUR 1 thousand, whereas, the majority of European enterprises significantly limited outputs in comparison with the year 2009 [22].

SME sector's participation in investments of enterprises sector was ranging during the years $2003-2011$ between $44 \%$ and $50 \%$, whereas, in last two years it insignificantly exceeded $50 \%$. One should also note that whole SME sector contributes value of resources to investment activities that is comparable to the one of big enterprises. The value of SME investment outputs in 2011 amounted to PLN 80.8 million, whereas, in case of big enterprises - PLN 80.4 billion and was bigger by $13 \%$ in case of SME sector and by $14 \%$ in case of big enterprises, in comparison with previous year [22].

The motion presented in the report is very interesting, as it concerns the amount of revenues in particular types of SME sector enterprises on the investment activities, "and thus, as a rule, one can note that along with the increase of the size of enterprise the amount of investment outputs in revenues increases, although differences between particular categories of sizes of enterprises are not as big, and in micro enterprises it amounts to $3.72 \%$, in small $-3.61 \%$, in medium $-4.39 \%$, and in the biggest ones $-4.98 \% "$ [22].

In the quoted report, the investment activities of enterprises in selected European countries in 2010 have been characterized and are as follows: „in comparison with other countries, investments in fixed assets of an average company in Poland (EUR 23.4 thousand) are significantly lower than the ones of its equivalent from more developed European countries - Switzerland (EUR 248.23 thousand), Norway (EUR 116.96 thousand), Austria (EUR 104.51 thousand), or even Latvia (EUR 29.29 thousand), Croatia (EUR 30.32 thousand) and Spain (EUR 31.52 thousand). With regard to the amount of fixed assets per 1 enterprise, Poland is on the 19th place among presented EU states, coming before states such as: Lithuania (EUR 22.93 thousand), Portugal (EUR 21.44 thousand), Bulgaria (EUR 20.90 thousand), Hungary (EUR 19.70 thousand) and the Czech Republic (EUR 19.55 thousand). One should note that a year before, i.e. in 2009, only Hungary had lower result than Poland. In 2010, Poland was included among a small group of countries (Norway, Ireland, Germany, Great Britain, Sweden, Romania, Cyprus, Italy, Spain) that experienced an increase of outputs on fixed assets of an average company in comparison with 2009. Despite an improvement in the level of investment outputs of enterprises in enumerated countries in 2010 , these are still lower than the results from 2008 - on average by $31 \%$ for all presented countries.

Poland was included among countries (Norway, Austria, Ireland, Germany, Sweden, Cyprus, Hungary and the Czech Republic), where $20 \%$ of drop in outputs, in 2010 , was noted in comparison with 2008, therefore, with time, the biggest economic slowdown in euro zone and the USA. Countries where the biggest drops in outputs were noted in comparison with 2008 are as follows: Slovakia (86\%), Latvia (64\%), Bulgaria (54\%), Slovenia (45\%), Luxemburg (44\%), Estonia (43\%), and Croatia (443\%). Italy was the only country that experienced an increase in investment outputs per one enterprise in comparison with 2008 (by $6 \%)[22]$. 
While analyzing contemporary structures of assets, one can clearly notice a shift in the direction of assets of intangible assets' character. One can enumerate such valued positions as: brand, know-how, licenses and others. In contemporary enterprises (in particular, in big international corporations) one can notice in the structure of assets a dominance - both, with regard to the structure and value of particular intangible assets' position, including intangible assets - with regard to the value of tangible assets. Recognizing this aspect in SME sector's enterprises, including craft enterprises, is extremely interesting. A separate aspect constitutes studying a level of awareness of this type of possible intangibles in assets structure in SME sector, including craft enterprises. Currently, a literary query does not allow any stipulation of trustworthy data regarding this extremely interesting area of SME sector enterprises' functioning, including craft enterprises. This aspect can turn out significant for contemporary markets (both in real and digital environment) in financing investment as well as all activities of SME sector enterprises, including craft ones.

Furthermore, the aforementioned report presented very interesting results of researches related with sources for financing SME sector enterprises on the Polish market. Sources for financing were defined as follows: „In 2011, similarly as in previous years, domineering source for financing SME sector investments in Poland were own resources $-63.4 \%$. Second place was taken by resources coming from national credits and loans $-17.5 \%$, and third place - by foreign resources $-9 \%$. Significantly lower meaning was attributed to remaining sources such as: budget resources $-3.6 \%$, other sources $-5.3 \%$ or unfinanced outputs $1.2 \% "$ [22].

The bigger the enterprise, the bigger the engagement of own resources for financing investments (small companies - 59.44\%, medium $-65.58 \%$, and big $-73.72 \%$ ), what is decided by their economic potential. National budget resources are mainly used by big enterprises $(4.72 \%)$, then small $(3.68 \%)$ and medium ones $(3.34 \%)$, which means that big enterprises more frequently use public resources than small ones, whereas, the investment scale in big companies is higher. On the other hand, small enterprises are a leader in using credits and loans (small -
$19.26 \%$, medium $-16.3 \%$, big $-5.99 \%$ ) and foreign resources (small 10.81\%, medium $7.98 \%$ and big $5.62 \%$ ). The biggest changes in the structure of financing investments in comparison with 2010 can be observed in small and big enterprises. Small companies in 2011, to a bigger extend financed investments from credits and loans (an increase by 2.61 p.p.), whereas, they used foreign resources to a lower extend (a decrease by 3.53 p.p.). Simultaneously, other sources input increased (by 2.52 p.p.) in their financing structure. Big companies to a bigger extend than in the previous year used their own resources (an increase by 2.34 p.p.), resigning in exchange from financing from national credits and loans (a decrease by 2.38 p.p.) and using to a bigger extend other sources (an increase by 2.83 p.p.) [22].

Another important issue is the output structure in compliance with fixed assets groups. In the quoted report, this issue was characterized in the following manner: „structure of investment outputs in compliance with fixed assets groups in SME, in 2011, had a tendency to remain at a similar level to the one in 2010. SME allocate the majority, i.e. half of the resources intended to investment, into buildings and construction (50.8\%). On the other hand, one third of investment resources is allocated to machines and equipment (30.9\%), whereas, there is a downwards tendency noticeable in this category (a decrease from $44.4 \%$ in 2006). In case of remaining groups of fixed assets, e.g. means of transport, it is difficult to determine trends. The smaller the enterprise, the bigger the share of outputs on buildings and construction (micro - 54.6\%, small $-62.1 \%$, medium $-41.0 \%$, big $-39.9 \%$ ) and means of transport (micro $-23.7 \%$, small $-11.1 \%$, medium $-18.0 \%$, big $-9.0 \%$ ). It is caused by a smaller economical potential of small entities and the cost scale related with this type of investments. Therefore, smaller entities can allocate to the equipment such as machines and devices relatively less resources (micro - 27.1\%, small - 25.6\%, medium $40.5 \%$, and big $-49.9 \%$ ), which causes their technological underinvestment" [22].

A separate and extremely important issue related with financing the activity of SME sector enterprises, including the craft ones, apart from investment activity comprises in financing current operations, e.g. as purchase 
of materials and raw materials necessary to produce services, energy and others. Another crucial issue related with functioning and financing activities of enterprises of this sector, including craft ones, comprises in e.g. market (clients) dictate, where they locate their products and services by forcing long payment terms (granting commercial credits). Additionally, SME sector enterprises, including craft ones, generate the need for financial resource filling in the gap resulting from financing their clients.

Moreover, the article defines the area related with availability of selected tools, instruments and conceptions for financing functioning of craft enterprises.

\section{Research Methodology}

Research results presented herein are based on the information collected as a result of a survey conducted among craft enterprises. The territorial area of researches of craft enterprises' functioning covered all voivodeships. Currently, in Poland there are approximately 330,000 craft enterprises registered in the Polish Craft Association. On the grounds of this number, a research sample was defined at a level of 1,422 craft enterprises. The research sample was selected at random. During conducting research, two research layers were considered. First, territorial one (covering all territory of Poland, since all voivodeships are basically correlated with craft chambers); second one: a form of conducted activity (very important from the point of view of obtaining selected tools and instruments for financing craft enterprises). The period of conducting researches among craft enterprises associated in the Polish Craft Association covers all year 2013.

The tailor-made survey, used to conduct the research, included a set of orderly questions corresponding to the goal of the research. At the beginning of the survey a register characterizing the enterprises that participated in the survey was placed.

The authors decided to use this form of research due to the fact that the survey questionnaire is a useful tool to receive the respondents' opinion. The information obtained from the respondents by means of questionnaires provided the team with valuable information which enabled to reach proper conclusions.

Survey research is one of the most frequently used and the most commonly quoted type of public opinion research. As a matter of fact, due to two elements i.e. simplicity and usefulness, it is the only tool used on a widescale in the scientific projects, also worldwide. It is extremely useful during the research conducted among companies since it enables segmentation, construction of an enterprise profile as well as provides information about the opinions and preferences of the respondents.

The survey, if skillfully used, gives enormous possibilities to conduct basic analysis and provide comprehensive insight.

The survey questionnaire was prepared in a classical (paper) version as well as electronic one. In order to execute researches with the use of a survey questionnaire in a classical version, craft chambers functioning in each voivodeship in the territory of Poland, guilds associated within particular craft chambers and the Polish Craft Association associating all craft chambers and guilds in Poland were asked for cooperation.

Furthermore, within virtualization of functioning of craft enterprises and institutions associating them (guilds, craft chambers, the Polish Craft Association), an electronic version of a survey questionnaire was also prepared. Unfortunately, this form of conducting researches failed. A return of sent survey questionnaires reached a level of $3 \%$. The result being a consequence of a lack of or a low degree of using digital environment in functioning of craft enterprises inclines to conclude on the necessity to conduct detailed researches on this element of functioning of craft enterprises operating in dynamically developing digital environment - the Internet. The return of survey questionnaires prepared in a classical form amounted to approximately $90 \%$, which gives 1,280 responses.

A method of participant observation was applied in researches on craft enterprises. Two co-authors of the article work or cowork with craft chambers and with the Polish Craft Association. This method proved to be particularly useful while formulating and verifying motions.

The survey questionnaire included 11 questions - open and closed. In order to obtain the fullest picture of researched craft enterprises, the questions concerned: a form of conducted business activity, net income for the previous year, a number of employed persons and characteristics of an enterprise. Second group of questions concerned the area related 
with financing craft enterprises, among others, referring to using such instruments, tools and conceptions for financing enterprises, as: credit, leasing, factoring, loan or subsidy. What is more, the survey questionnaire included questions allowing defining barriers in using them by the craft enterprises. It also contained questions on European Union funds as a source of financing, as well as questions regarding using help of institutions supporting entrepreneurs from socalled business environment.

\section{Research Results}

Enterprises associated in the Polish Craft Association participating in the research represent 26 crafts enumerated below:

- painter-decorator -31 ,

- carpenter-84,

- butcher-meat processing technician - 17 ,

- bricklayer - 109,

- motor vehicles mechanic - 161,

- motor vehicles electro-mechanic-32,

- vehicle whitesmith - 46,

- varnisher - 33,

- confectioner - 131,

- baker - 134,

- hairdresser - 156,

- tailor - 13,

- electrician - 39,

- tire fitter - 11,

- watchmaker-3,

- wood worker - 36,

- roofer -49 ,

- locksmith - 19,

- floorer - 17 ,

- goldsmith-jeweler - 24,

- upholsterer - 12,

- water and sanitary devices fitter - 36,

- gas devices fitter - 26,

- chimney sweeper - 14 ,

- construction finishing works process engineer -44 ,

- blacksmith -3 .

Researched craft enterprises had various legal forms, starting from natural persons conducting economic activity, through civil partnerships, registered partnerships and limited liability companies. From among associated enterprises the majority, i.e. $65.55 \%$ of surveyed companies, were made by natural persons conducting economic activity.

In order to learn more about research craft enterprises, the survey also included a question concerning a number of persons employed in an enterprise.

The number of employed persons in researched craft enterprises associated in guilds was as follows:

- up to 10 persons are employed by 839 from among research companies, which constitutes $65.55 \%$,

- 11-50 persons are employed by 441 from among research companies, that is, $34,45 \%$.

The size of companies broken down by the type of craft is presented in Fig. 1. Fig. 1 presents data of micro-enterprises as well as small enterprises taking into account each group of respondents as $100 \%$ (separately for micro-enterprises and separately for small enterprises). Fig. 2 presents enterprises divided in accordance with the represented craft including all enterprises regardless of their size (1,280 companies).

\subsection{Using Instruments of Support for Enterprises, such as: Credit, Leasing, Factoring, Loan, Subsidy and Others}

As a result of analyzing the information from survey questionnaires it was stated that a majority of researched enterprises $-45.00 \%$ (including $23.20 \%$ of micro enterprises and $21.80 \%$ of small enterprises) used a credit as a manner of financing activity regarding investment as well as operations (Fig. 3). Presented result is identical as the one presented in other sources. Craft enterprises did not indicate any type of credit, its hedging or purpose, e.g. investment or operational.

Leasing as a form of financing (in the layer of fixed assets) was used by $27 \%$ of researched companies (including 20.78\% of micro enterprises and $6.25 \%$ of small enterprises). In a prevailing part, respondents pointed to operational leasing as a basic type of used leasing - a way of financing investments - fixed assets. Among others, the use of lease back in craft enterprises regarding tangible and intangible fixed assets was not noted in the research. A lack of using such a conception for financing increases the risk of craft enterprises' functioning on the Polish market.

The results of researched craft enterprises show that $12.03 \%$ of enterprises used borrowing $(10.63 \%$ micro and $1.41 \%$ small). It came as 


\section{Fig. 1: Craft types broken down by the company size}

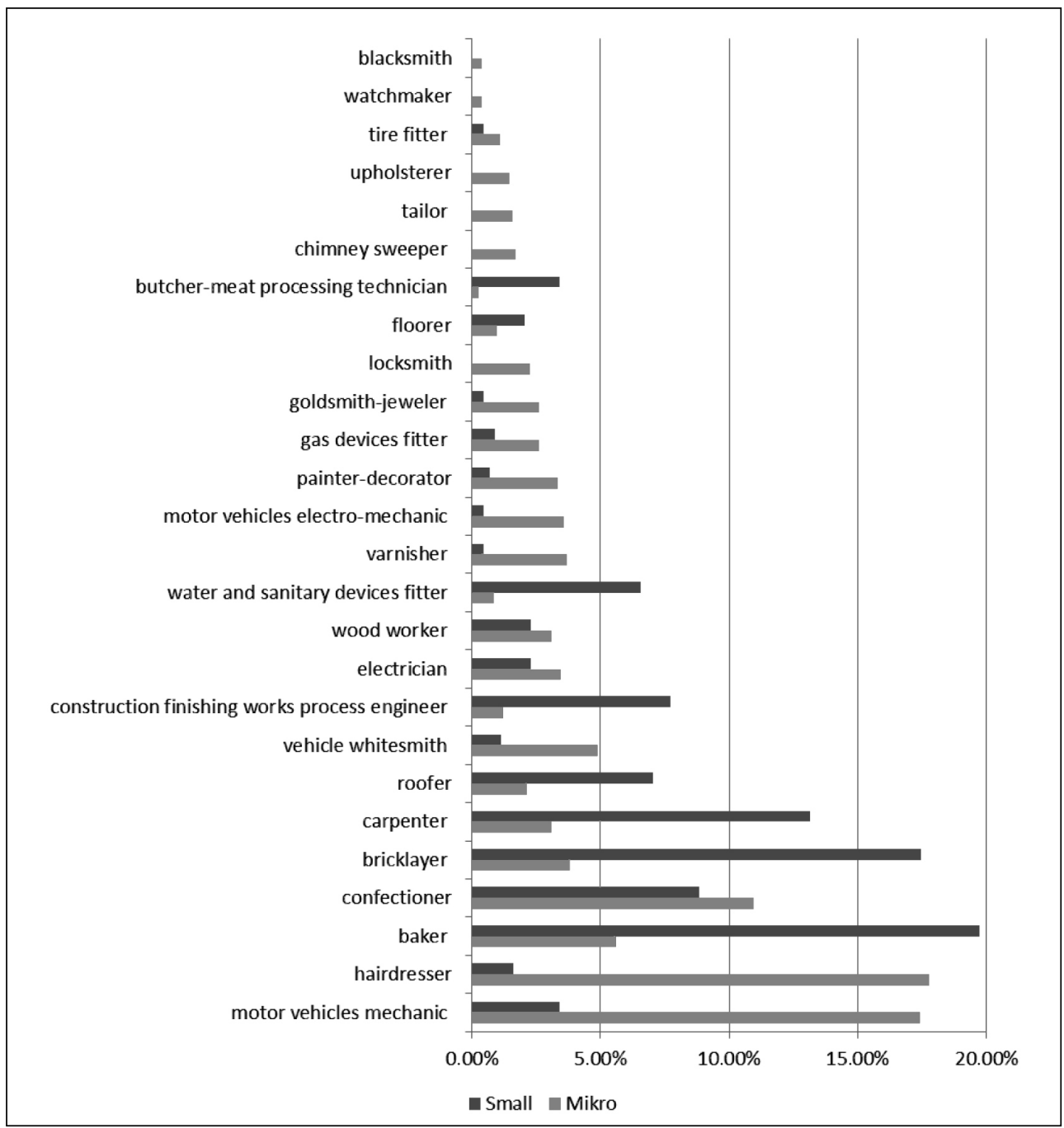

Source: own

a huge surprise that only one enterprise used factoring. Due to big payment gridlocks occurring on the Polish market, it might seem that factoring is a conception that allows: speeding up trading, lowering the risk of enterprise's functioning (the bank acts as an analyst of risk of SME sector enterprises' clients), maintenance of solvency at a relevant level. Among reasons for the aforementioned situation one can definitely define the following factors:
1. Availability of the service aimed at enterprises and offered by the banks and their boundary conditions.

2. Education of the craft enterprises' owner on the advantages and disadvantages of using factoring.

3. Economic-financial results for craft enterprises (a level of necessary payments for the enterprise - particularly important with a low profitability of provided products and services). 


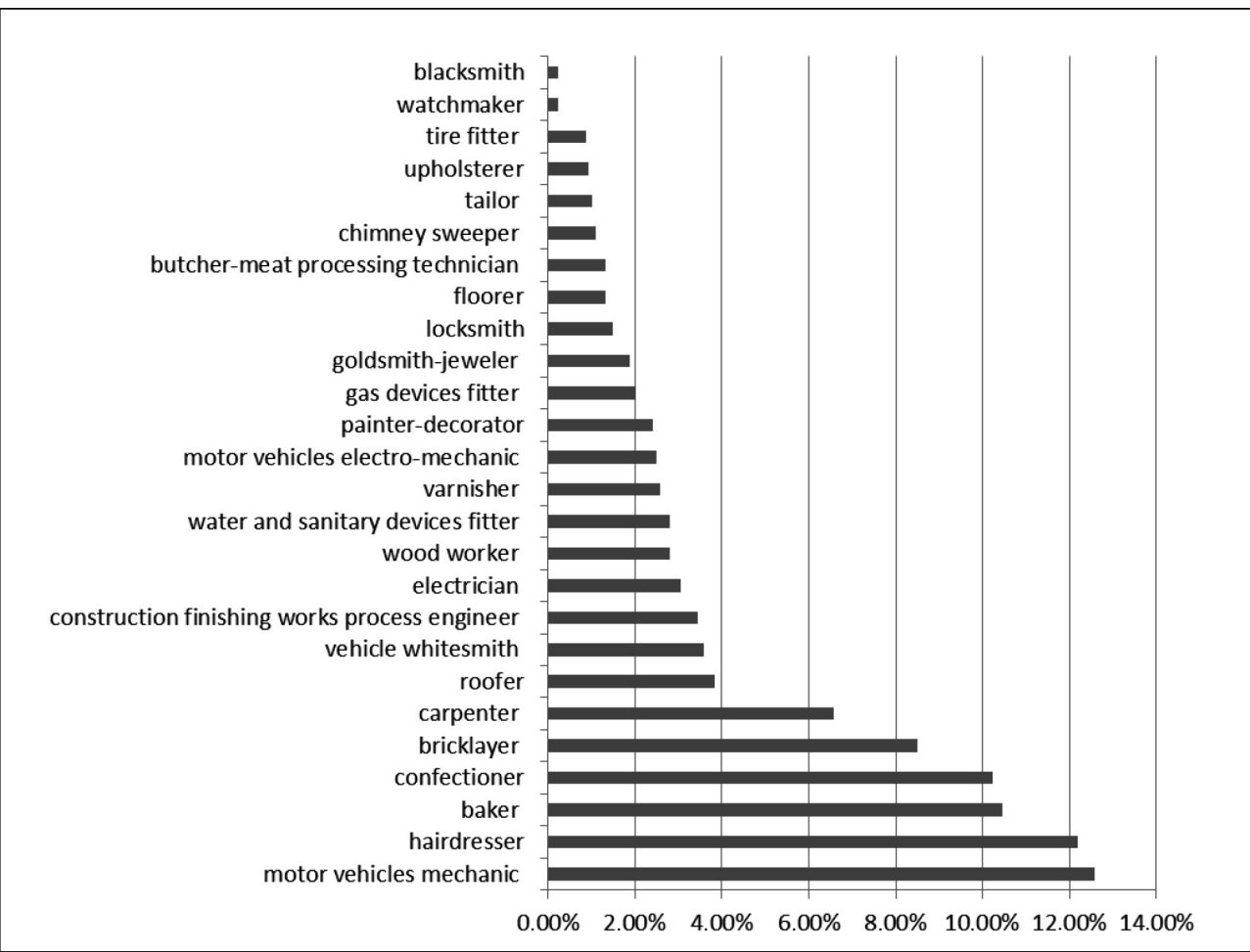

Source: own

Using subsidies was reported in total by 52 enterprises, which constitutes $4.06 \%$ of the surveyed entities. Subsidies were allocated to:

- establishment of a new workplace - in case of 17 enterprises,

- setting up an enterprise - in case of 35 enterprises.

No surveyed enterprise enumerated other support instruments that could be used by them. The results showed that $15.45 \%$ of micro enterprises did not indicate any form of support, however $8.75 \%$ of small companies does not use any of the enlisted support instruments.

\subsection{Using National, European Union Funds}

Question 4 included in the survey questionnaire was as follows: Did the enterprise use or has been using national, European Union funds or did the enterprise apply for them?
Only 189 (that is: $14.77 \% ; 8.91 \%$ micro and $5.86 \%$ small companies) from among researched enterprises associated in guilds answered this question affirmatively. Remaining enterprises never used and do not use any such funds and never applied for them. This result shows a very negative phenomenon confirmed in conducted researches implying functioning of craft enterprises particularly in the context of an "old" (2007-2014) perspective of financing with European Union resources. It also points to a big challenge in this aspect, in a new perspective of financing projects with European Union resources (2014-2020). Among reasons for such a situation, one can, among others, define to following factors:

1. Competence barrier in drawing up a relevant motion to an institution financing projects.

2. Addressing priorities and terms and conditions of announced contest improperly. 
3. Economic-financial barrier for craft enterprises (big fees paid "in advance") for drawing up projects.

4. Improper structure of announced contests on so-called soft projects and so-called hard - investment projects.

5. A long period of time in possibility of commercial use of realized projects ( 3 or 5 years depending on a level of subsidy).

6. A long period of drawing up, assessment and taking decisions for projects.

\subsection{Subject of Funding}

Another question included in the survey questionnaire regarded a subject of funding from among enumerated support forms. As an answer, 10 propositions were made and a possibility to give other answers was also given.

Most often researched craft enterprises allocated obtained financing to construction and renovation - according to answers given by as many as 320 respondents, which amounts to $25 \%$ of researched enterprises

\section{Fig. 3: Support instruments for companies}

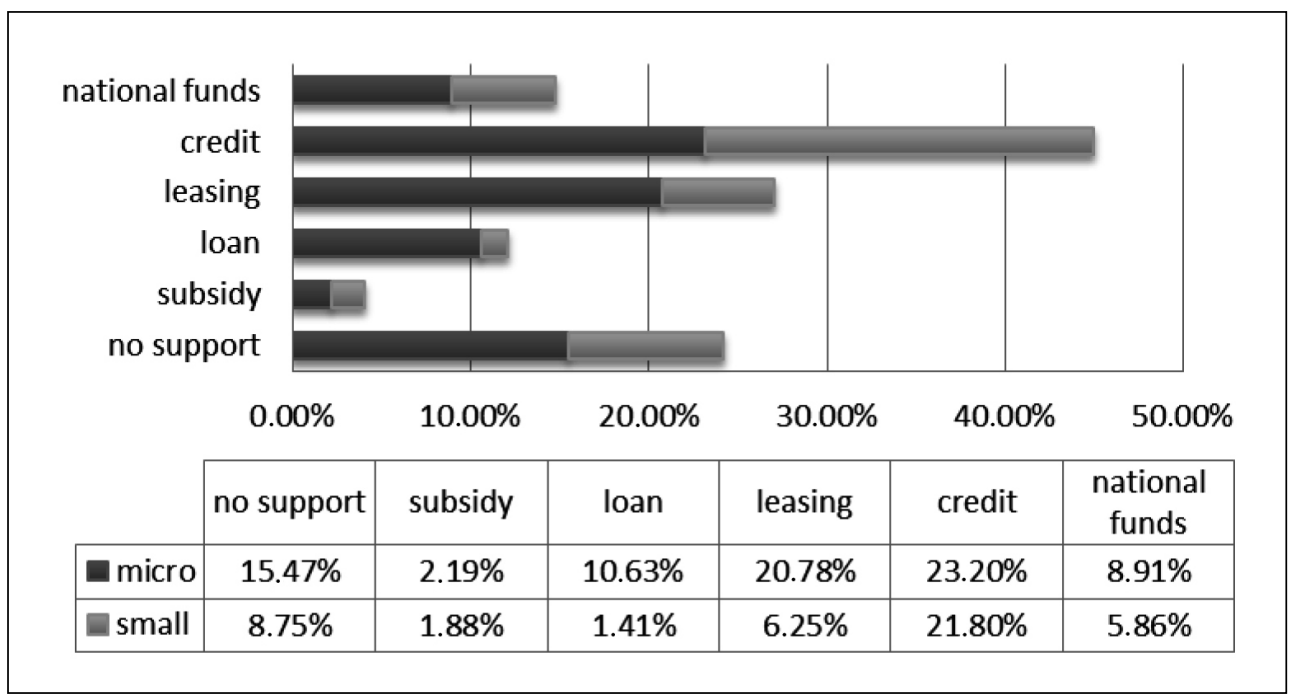

Source: own

(Fig. 4). This result is slightly different from the one presented in a report on the SME sector situation, where $50 \%$ of micro enterprises allocate obtained funds to investments in buildings and constructions. In case of craft enterprises functioning, as a rule, for several years or several dozens of years (in majority, family enterprises), managed to establish during many years of activity a proper level of fixed assets, including in a form necessary for production and services provided for buildings and constructions.

Next in terms of size subject of funding craft enterprises were machines and devices, which was indicated by 269 enterprises (19\%). From the point of view of innovative behaviors and limitation of risk of craft enterprises' functioning on the Polish market, this result is unsatisfactory. However, it should be noted that the view in this aspect is unclear, among others, with regard to using all types and varieties of leasing. Also common use of outsourcing (according to different types, functions, products, services and conceptions) allows an access to the newest technical-technological solutions and, therefore, an access to modern machines and devices without a need to buy them, at the same time limiting a risk of such an investment.

Among researched craft enterprises, 20\% allocated obtained financial resources to buying means of transport. 
Purchasing real estates was indicated by $9 \%$ of craft enterprises. Very disturbing results were stated in the area of craft enterprises' financing for new technologies (know-how), where only $4 \%$ among the researched entities confirmed purchasing them with obtained financial resources. In order to raise competitiveness and, at the same time, to decrease the risk of craft enterprises' functioning, it is necessary to drastically increase a share of financing purchases of know-how, licenses and other intangible assets. Other aspect functioning in correlation with this area is the use of franchising.

Research result at a level of $6 \%$ in using financial resources by craft enterprises to conduct trainings for employees is commensurate to the situation of training market in Poland. Generally, the market is overregulated with an immense number of offered trainings, including free trainings proposed within socalled "soft" projects financed with European Union resources. A huge misunderstanding in this area comprises in e.g. a ban on conducting trainings certified with European Union funds, e.g. regarding health and safety at work - necessary and extremely important for functioning of each enterprise, including SME sector enterprise and thus, craft enterprise.

Purchase of hardware and software was confirmed by 68 enterprises. 23 enterprises, which constitutes a little more than $2 \%$ of respondents, allocated obtained financial resources to increasing employment. 53 enterprises allocated obtained resources to counseling services.

No researched enterprise allocated obtained resources to implementing certification in the enterprise. No respondents marked any other subject of funding than the ones enumerated.

\subsection{Barriers in Using Services}

Question no. 6 in the survey questionnaire regarded existing barriers in using services in

\section{Fig. 4: Subject of funding in given enterprises}

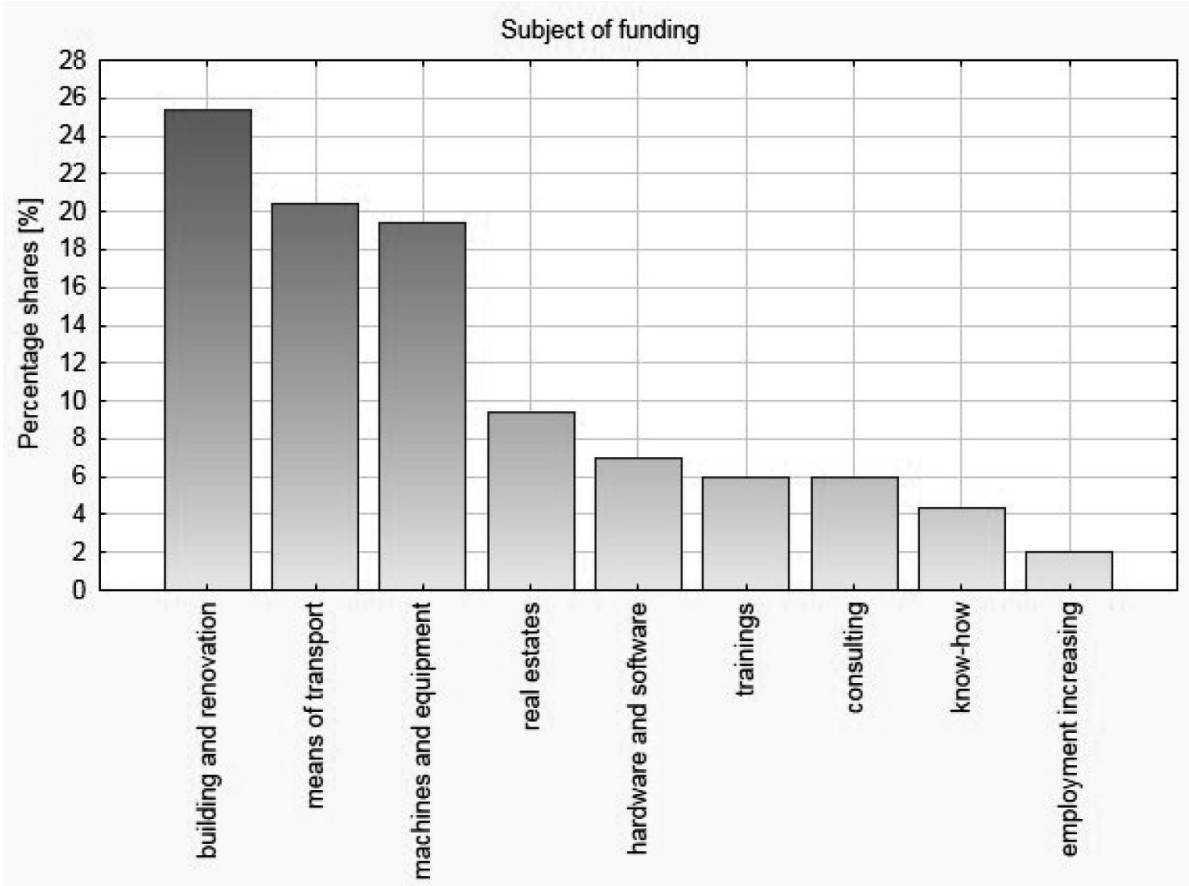


the subject of funding craft enterprises' activities. As a closed question seven possibilities and an answer "other (please enumerate)" were given. Respondents could have also circled several answers. Among barriers defined by craft enterprises the following were enumerated:

1. Too complex bureaucracy was indicated by as many as 1,139 respondents, that is $88.98 \%$ (57.42\% micro and $31.56 \%$ small).

2. Unsatisfactory hedging was indicated by as many as $39.06 \%$ (29.14\% micro and $9.92 \%$ small) of researched companies.

3. Poor economic-financial results of craft enterprises were pointed to by $18.98 \%$, that is, 243 enterprises.

4. A lack of own shares $-16.02 \%$ (10.08 micro and $5.98 \%$ small) pointed to this barrier.

5. Complicated provisions - $13.98 \%(8.91 \%$ micro and $5.08 \%$ small) of research subjects pointed to this barrier.

The results of the analysis are presented in detail in Fig. 5

A result of a research on barriers in using financing craft enterprises' activities, where a barrier related with bureaucracy is enumerated in the first place, constitutes a very disturbing phenomenon. The research results presented herein remain in correlation with the results presented by the Report drawn up by Bank PKO SA for all SME sector published in
2014. Among barriers indicated in this report, "bureaucracy burden" took fourth place in the list of the biggest influence (in $2012-3.51$ ) and in 2013, a result of 3.27 (where, 1 stood for a lack of barrier, and 5 - a very important barrier). In the same report, a barrier in form of "an access to external financing" took eleventh place on a list of the biggest influence with a result (in $2012-2.62$ ) and in $2013-2.34$. It is a clear signal for:

1. Polish legislator.

2. Banks.

3. Other financial markets' institutions.

4. Business environment institutions.

5. Local self-governments, in particular of a voivodeship level.

6. Employers' associations (including Craft Guilds and Chambers and the Polish Craft Association).

Bureaucracy as well as complicated procedures are one of the main obstacles in cooperation of small and medium enterprises with institutions offering external sources of financing. The problem is clearly observed in small and medium enterprises, and at the same time, it also is observed by institutions supporting entrepreneurship. According to the authors and entrepreneurs who participated in the research, the procedures concerning the required documents shall be simplified and the

\section{Fig. 5: Barriers in using services}

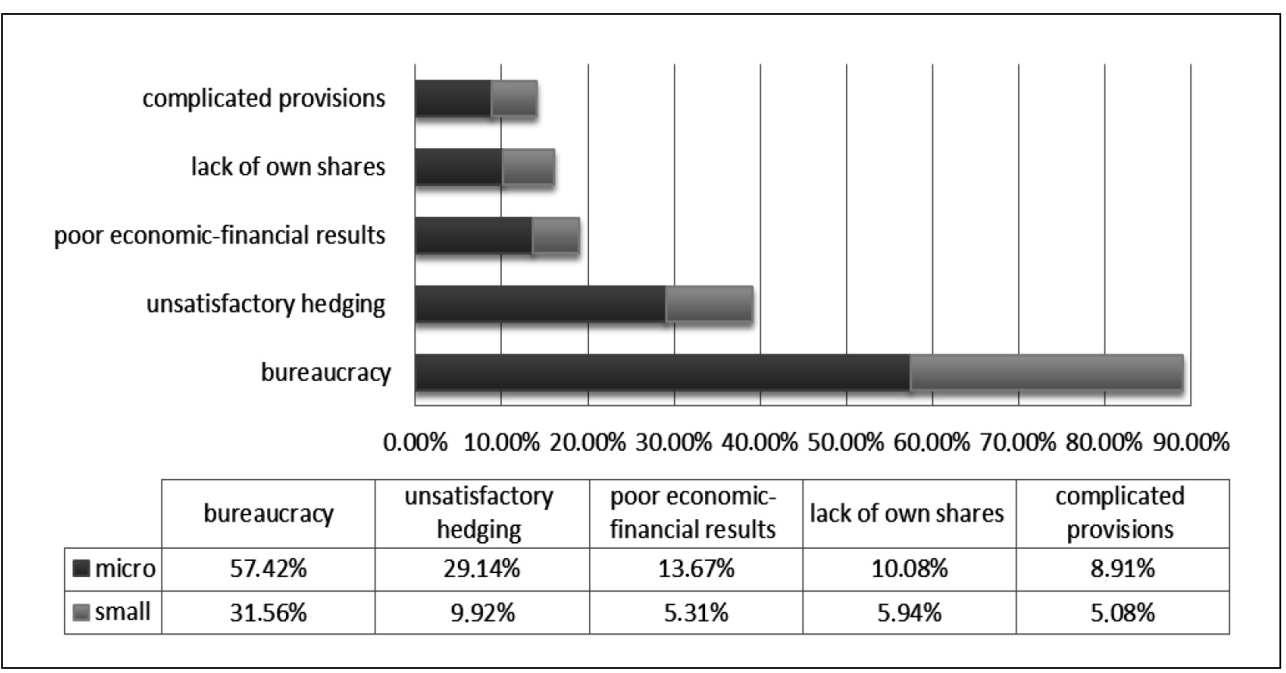


requirements before and after receiving the financial support shall be relaxed.

For the enumerated institutions and others these results constitute a serious signal for working over changing strategy regarding bureaucratic burdens in general, including burdens related with obtaining external financing for enterprises, including also craft ones. Among directions for changes one can definitely enumerate the following:

1. Increasing the use of digital environment (the Internet).

2. Bigger use of outsourcing by craft enterprises (in particular, regarding focusing on basic activity).

3. A change in the philosophy of the activity of business environment institutions from the area of consulting and trainings to the area of drawing up and implementing particular applications for example for: credits, leasing contracts, franchising contracts, outsourcing projects contracts and others with a minimum fee or, in selected cases, without fee.

\subsection{Assistance of Institutions Supporting Entrepreneurs}

Question regarding assistance of supporting institutions was as follows: Does the enterprise use the assistance of institutions supporting entrepreneurs? Two forms of answers were proposed: affirmative and negative. In case of an affirmative answer, one should have enumerated these institutions and described a scope of assistance.

Respondents from enterprises associated in organizations of craft economic selfgovernment many times used services of these organizations and indicated in their answers cooperating, among others, with institutions, such as:

- regional economic chambers,

- regional financing institutions,

- consultation points.

Support areas comprised in areas such as:

- environmental protection,

- public procurement,

- health and safety at work,

- labor law,

- training juvenile employees,

- financial forms of supporting craft activities,

- structural funds.

Another question concerned an assessment of hitherto cooperation between craft enterprises and these institutions. The results were as follows:

1. $57.97 \%$ respondents described the cooperation as very good,

2. $43.44 \%$ - as good.

The researches results show that within the area of relations and cooperation with business environment institutions (craft enterprises) many things should be supplemented and improved. This refers in particular to bureaucratic burdens defined in the context of research on barriers.

Tenth research question included in the survey questionnaire concerned an intention to use assistance of organizations and institutions supporting entrepreneurs in the future. $100 \%$ of surveyed associated enterprises answered this question affirmatively, which seems obvious, since they remain members of various craft guilds. Such a result of researches is on one hand very interesting, among others, due to:

1. The possibility to network craft enterprises, including defining clusters.

2. Strong representation ("voice" in discussion and implementation) in defining and implementing projects eliminating e.g. bureaucratic barriers.

3. The use of a synergy effect, e.g. in creating intangible assets, creating and hedging intellectual property of particular craft enterprises as well as their employees.

4. Effective competition on the global market in spite of functioning on a local market.

5. Optimization of a risk of conducting activity by craft enterprises.

On the other hand, it provides new requirements in co-operation (e.g. direction of the development of co-operation through clusters) between craft enterprises, their relation with closer and further environment institutions, as well as creating new competences both, as a craft enterprise and its particular employees, e.g. in the aspect of using virtual space.

\subsection{Micro vs. Small Craft Enterprises - Statistical Differences}

Additionally, statistical analysis for the purposes of statistical hypothesis verification was conducted:

„Is the difference between the craft enterprises employing up to 10 employees and enterprises employing from 11 to 50 employees statistically relevant?"

For this purpose, 11 characteristics defined for micro enterprises and small enterprises were taken into consideration. The variables included 
the following data: using support instruments such as credit, leasing, loan or grant as well as not using any forms of support, using national funds, barriers hindering financing services such bureaucracy, insufficient security measures, weak economical and financial results, lack of equity contribution and complicated regulations. For this purpose structure index (statistical test for two structure index; partial tests of proportions between small and micro enterprises) was used.

This test assume: tested feature $X$ in the two populations has a distribution two-point (zero-one) with unknown parameters $p_{1}$ and $p_{2}$, respectively. We have two samples with frequency $n_{1}, n_{2}>100$ and we assume $\alpha=0.05$.

$\mathrm{H}: \mathrm{p}_{1}=\mathrm{p}_{2}$

$\mathrm{K}: \mathrm{p}_{1} \neq \mathrm{p}_{2}$.

The test results showed:

\section{A. Support instruments for companies:}

True hypothesis $\mathrm{K}: \mathrm{p}_{1} \neq \mathrm{p}_{2}$. Index $p_{1}$ and $p_{2}$ are statistically different for: 1 . credit, 2 . leasing, 3 . loan.

Micro and small enterprises differ significantly from each other in case of "credit", "leasing" and "Ioan" as a one of support instruments for companies.

True hypothesis $\mathrm{H}: \mathrm{p}_{1}=\mathrm{p}_{2}$. Index $p_{1}$ and $p_{2}$ are not statistically different (they are the same) for: 1 . subsidy, 2. no support, 3. using national funds.

Micro and small enterprises does not differ significantly from each other in case of "subsidy", "no support" and "using national funds" as a one of support instruments for companies.

B. Barriers in using services in financial subject:

True hypothesis $\mathrm{K}: \mathrm{p}_{1} \neq \mathrm{p}_{2}$. Index $p_{1}$ and $p_{2}$ are statistically different for: 1 . bureaucracy 2. unsatisfactory hedging 3 . poor economicfinancial results.

Micro and small enterprises differ significantly from each other in case of "bureaucracy", "unsatisfactory hedging" and "poor economicfinancial results" as barriers in using services in financial subject.

True hypothesis $\mathrm{H}: \mathrm{p}_{1}=\mathrm{p}_{2}$. Index $\mathrm{p}_{1}$ and $\mathrm{p}_{2}$ are not statistically different (they are the same) for: 1. lack of own shares, 2 . complicated provisions.
Micro and small enterprises does not differ significantly from each other in case of "lack of own shares" and "complicated provisions" as barriers in using services in financial subject.

\subsection{The Knowledge of Possibilities of Financial Support from European Union Funds}

This question was posed in the following way: Is the enterprise familiar with possibilities of financial support from European Union funds? Three possible answers to this question were proposed:

a) Yes.

b) No, but I am interested in learning about such an offer.

c) No, since we shall not be applying for such a form of support.

The results of researches show that as many as $63 \%$ of craft enterprises pointed to option b).

Such result is surprising, considering the period and number (including, in particular, the number of trainings and other "soft" projects theoretically providing knowledge on the aforementioned researched topic) of realized European Union projects and even projects realized before accession and a number of engaged institutions and enterprises. This result shows, that on the Polish market there is a problem with the quality (effectiveness) and type of projects defined within contests on using European Union funds, including using funds for drawing up particular projects, including the ones addressed at craft enterprises.

\section{Conclusions}

Identification of sources for financing activity (both, in the investment and operational aspect) of craft enterprises constitutes a complex process. Decisions related with obtaining financing in particular for SME sector enterprises, including the craft ones, are of a strategic character. Consequences of wrong decisions can turn out disastrous not only for the development, but also for further functioning of the enterprise, its "survival" on the market. Criteria that can be used for selection thereof include:

- development strategy,

- a level of the need for resources,

- cost and general terms and conditions of obtaining resources,

- preferences of the owner with regard 
to the type of allocation e.g.: buildings, constructions, machines, equipment, knowhow and others,

- a level of the enterprise's indebtedness,

- local financial infrastructure (in a form of functioning subsidiaries, branches of various financial markets' institutions e.g. banks, factoring enterprises, leasing enterprises and others),

- SME development support system, provided, predominantly, by institutions of closer or further environment thereof.

Preferences for particular sources decide on the choice between internal and external capital [28]. From the point of view of the enterprise's development, the ownership structure of the capital, including own and foreign capital, has a significant meaning while selecting a financing source. It has a crucial meaning in the context of possible decisions taken by the enterprise in order to obtain external financing sources, credit rating assessment and others.

A literary query conducted within this scope shows that own resources, credits, leasing and loans are used as a financing form for craft economic activity of enterprises associated in organizations of craft economic self-government.

The results of conducted researches confirm that craft enterprises at a level of $45 \%$ use credits as a source of financing their operative as well as investment activity. Financing conceptions such as: leasing, loans, outsourcing, factoring, sale of shares, issue of bonds and others are enumerated as next ones.

Small number of craft enterprises use national and European Union funds. Thus obtained capital was allocated by the craftsmen mainly to constructions and renovations, machines and equipment, means of transport and real estates.

The results of researches presented herein remain in correlation with the results of researches presented among others in reports:

- from 2013, on the situation of SME sector drawn up by PARP,

- from 2014, on the situation of SME sector enterprises issued by Bank PKO SA.

The research results are in correlation with the data included in the scientific publications. The vast majority of small and medium companies uses self-financing for the purposes of current and investment activities. With reference to foreign capital, an expensive and inaccessible credit is the most popular form of financing.

Enterprises have preferred to finance their investment from their own sources for many years, what is confirmed by the research conducted by the National Bank of Poland and the Central Office of Statistics [15], [31]. It is a structural factor limiting the credit demand among enterprises.

In many cases craft enterprises are familyowned ones with a tradition of many years (or even several hundreds of years) and they conduct diversified and determined by their specific character policy of obtaining sources for financing comprising in:

- using defined (determined with e.g. many years of cooperation) sources of financing, what in selected cases results even in sole dependency on a particular institution of financial market, even at the expense of the effectiveness of used financial instruments,

- limited trust in modern instruments for financing activity, such as, e.g.: factoring, outsourcing and others,

- significant criterion for this type of enterprises remains a limited risk in using financial instruments,

- precise estimation of the risk of family enterprise's functioning (of a craft enterprise) with the basic criterion - the functioning time of the enterprise for future generations,

- higher awareness of family enterprises, including craft ones, in comparison with other enterprises, also the SME sector, to the required by financial markets institutions co-financing in particular instruments e.g. own participation in loans, national and foreign (e.g. European Union) subsidies and others,

- higher awareness of family enterprises, including craft ones, in comparison with other enterprises, also the SME sector, of the consequences of obtaining external sources for financing operational and investment activities, e.g. in the context of granted credit's hedging.

Results of researches presented, among others, in quoted, periodical reports (issued by PARP and Bank PKO SA) show that in many cases, family enterprises, including craft ones of such character, prefer using sources, such as: 
- Owner's own resources,

- owner's family resources,

- loans from friends,

with all related consequences, e.g.: economicfinancial, tax, legal and social, many times negative ones.

Irrespectively of reasons for such type of behaviors, they bring about essential benefit comprising in engaging in economic activity resources that have been put aside for socalled a rainy day [5].

According to the report on the situation of micro and small enterprises, the year 2012 (Report issued by Bank PKO SA) brought about an increase in new credits for enterprises. Own resources remained the most frequent source for financing investment in companies. Banks sharpened credit policy in the enterprise segment, predominantly with regard to margins and required hedging [22], [23], [24]. 2013 was a year that characterized with a low speed in increase of enterprises' credits and companies once again most frequently financed new investments with own resources. In 2013 enterprises applied for a credit less frequently than in 2012. The most frequent reasons for rejecting applications for credits comprised in a lack of credibility or credibility inadequate with banks' requirements [16]. This study includes results of researches conducted on a very important area and presents them both, from the point of view of craft enterprises and stakeholders from their closer and further environment, that is, it defines barriers in obtaining resources for financing operational and investment activities of these enterprises.

Craft enterprises pointed to some barriers, among others:

- as the main barrier - too complicated bureaucracy,

- the second - unsatisfactory hedging (a lack of own share) that craft enterprises must be at a disposal of.

Further, defined barriers with the biggest share in their structure refer to both, craft enterprises (predominantly, with regard to the economic-financial condition), and, predominantly, indicate much too big imperfection of relations with institutions of their closer and further environment. Many of the aforementioned institutions should, as a rule, eliminate defined barriers in a direct form, e.g.: through organizing low interestbearing loan funds together with banks from
European funds. In this aspect, accepting and dividing risk related with financing particular projects in craft enterprises remains extremely valuable and, to same extend, bureaucracy should be limited to an essential and necessary extend.

The fact that craft enterprises show a low level of using modern instruments and conceptions for financing their investment and operations activities, including e.g.: factoring, lease back, outsourcing and others, should be strongly underlined. Nevertheless, mainly institutions functioning on financial markets must consider such business partners as craft enterprises at the same time assuming in the initial phase of cooperation that they shall have to incur bigger outputs to draw up particular projects predominantly due to a low level of specialist competences of craft enterprises. In the long run the result for institutions of financial markets (among others, as a consequence of mutual trust) shall comprise in the fact that the cooperation with craft enterprises shall generate an increase in revenues due to sales of own products both, with regard to the value and to the quality.

Due to the meaning of SME sector, including craft enterprises, in the economy of each country, elimination or limitation of defined herein barriers in obtaining financial resources both, on the operational and investment activity, as a consequence, contributes to survival and development of enterprises. The above situation translates into: generating new work positions, innovative behaviors of craft enterprises, including their employees, increasing craft enterprises' incomes, increasing state incomes and local community incomes.

The results of the conducted tests (structure index) showed that there are statistically relevant differences between the craft enterprises employing up to 10 employees and the enterprises employing from 11 to 50 employees in case of: "credit", "leasing", "loan", "bureaucracy", "unsatisfactory hedging" and "poor economic-financial results". The results of the conducted tests showed that there are not any statistically relevant differences between the craft enterprises employing up to 10 employees and the enterprises employing from 11 to 50 employees in case of: "subsidy", "no support", "using national funds", "lack of own shares" and "complicated provisions". 


\section{References}

[1] AYYAGARI, M., BECK, T., DEMIRGUCKUNT, A. Small and medium enterprises across the globe. Small Business Economics. 2007, Vol. 29, Iss. 4, pp. 415-434. ISSN 0921-898X. DOI: 10.1007/s11187-006-9002-5.

[2] BECK, T., DEMIRGUC-KUNT, A., LEVINE, R. SMEs, growth, and poverty: cross-country evidence. Journal of economic growth. 2005, Vol. 10, Iss. 3, pp. 199-229. ISSN 1381-4338. DOI: 10.1007/s10887-005-3533-5.

[3] BECK, T., LEVINE, R., LOAYZA, N. Finance and the Sources of Growth. Journal of financial economics. 2000, Vol. 58, Iss. 2, pp. 261300. ISSN 0304-405X. DOI: 10.1016/S0304405X(00)00072-6.

[4] BELÁS, J., et al. The business environment of small and medium-sized enterprises in selected regions of the Czech Republic and Slovakia. E+M Ekonomie a Management. 2015, Vol. 18, Iss. 1, pp. 95-110. ISSN 12123609. DOI: 10.15240/tul/001/2015-1-008.

[5] BIELAWSKA, A. The meaning of small enterprises for the economic development. Ekonomista. 1992, Vol. 3. pp. 465-468. ISSN 0013-3205.

[6] BUSCHFELD, D., et al. Identification of future skills needs in micro and craft (-type) enterprises up to 2020. Final report [online]. Cologne, Hamburg, Vienna: FBH, 2011 [cit. 2014-12-29]. 133 p. (PDF). Available from: http://futureskills2020.eu/files/SkillsNeeds_ Final_Report_EN_16.02.2011_final_R.pdf.

[7] CHEN, J., CHEN, Y., VANHAVERBEKE, $W$. The influence of scope, depth, and orientation of external technology sources on the innovative performance of Chinese firms. Technovation. 2011, Vol. 31, Iss. 8, pp. 362-373. ISSN 0166-4972. DOI: 10.1016/j. technovation.2011.03.002.

[8] DEMIRGÜÇ-KUNT, A., BECK, T., LEVINE, R. Small and medium enterprises, growth, and poverty: Cross-country evidence. World Bank policy research working paper 3178. World Bank, 2003.

[9] FOLTYS, J. Outsourcing in the sector of small and medium enterprises. Application scripts. 2012. Katowice: The Publishing House of the University of Silesia in Katowice, 2012. ISBN 978-83-226-2078-6.

[10] GAGLIARDI, D., et al. A recovery on the horizon? Annual report on European SMEs 2012/2013 [online]. Brussel: European Commission, 2013 [cit. 2015-01-02]. 99 p. (PDF). Available from: http://ec.europa.eu/ growth/smes/business-friendly-environment/ performance-review/files/supportingdocuments/2013/annual-report-smes-2013_ en.pdf.

[11] Journal of Laws of 1927, No. 53, item 468, as amended.

[12] Journal of Laws of 1972, No. 16, item 94.

[13] Journal of Laws of 1977, No. 4, item 20.

[14] Journal of Laws of 2002, No. 112, item 979 , as amended.

[15] KOWALSKI, S. Financing sources for small and medium enterprises in Poland including the EU structural funds. The economics and the organization of food economy. 2009, Vol. 76, pp. 157-164. ISBN 978-83-7583-137-5.

[16] KROLCZYK, J., LEGUTKO, S. Innovation as a Key Factor for Entrepreneurial Activity. Applied Mechanics and Materials. 2014, Vol. 657, pp. 1046-1050. ISSN 1662-7482. DOI: 10.4028/www.scientific.net/AMM.657.1046.

[17] KUBíČKOVÁ, L., PROCHÁZKOVÁ, L. Success evaluation of small and medium-sized enterprises in terms of their participation in the internationalization process. $E+M$ Ekonomie a Management. 2014, Vol. 17, Iss. 2, pp. 131-145. ISSN 1212-3609. DOI: 10.15240/ tul/001/2014-2-010.

[18] NIETO, M.J., SANTAMARÍA, L. The importance of diverse collaborative networks for the novelty of product innovation. Technovation. 2007, Vol. 27, Iss. 6, pp. 367-377. ISSN 0166-4972. DOI: 10.1016/j. technovation.2006.10.001.

[19] LASAGNI, A. How can external relationships enhance innovation in SMEs? New evidence for Europe. Journal of Small Business Management. 2012, Vol. 50, Iss. 2, pp. 310339. ISSN 0047-2778. DOI: 10.1111/j.1540627X.2012.00355.x.

[20] LOVE, J.H., ROPER, S. Location and network effects on innovation success: evidence for UK, German and Irish manufacturing plants. Research policy. 2001, Vol. 30, Iss. 4, pp. 643661. ISSN 0048-7333. DOI: 10.1016/S00487333(00)00098-6.

[21] RAMMER, C., CZARNITZKI, D., SPIELKAMP, A. Innovation success of nonR\&D-performers: substituting technology by management in SMEs. Small Business Economics. 2009, Vol. 33, Iss. 1, pp. 35-58. ISSN 0921-898X. DOI: 10.1007/s11187-009-9185-7.

[22] Report on the condition of small and medium-sized enterprise sector in Poland in 
2011-2012 [online]. Warsaw: Polish Agency of Enterprise Development, 2013 [cit. 2014-1117]. 248 p. (PDF). Available from: http://www. parp.gov.pl/files/74/81/626/18355.pdf. ISBN 978-83-7633-284-0.

[23] Report on the situation of micro and small enterprises in 2012 [online]. Warsaw: Bank Pekao S.A., 2013 [cit. 2014-11-17]. 493 p. (PDF). Available from: http://www.pekao.com.pl/binsource/f/00/ Raport_2013_pol.pdf. ISSN 2082-4610.

[24] Report on the situation of micro and small enterprises in 2013 [online]. Warsaw: Bank Pekao S.A., 2014 [cit. 2014-11-17]. 449 p. (PDF). Available from: http://www.pekao. com.pl/binsource/f/00/Raport_2014_pol.pdf. ISSN 2082-4610.

[25] ROGERS, M. Networks, firm size and innovation. Small business economics. 2004, Vol. 22, Iss. 2, pp. 141-153. ISSN 0921-898X. DOI: 10.1023/B:SBEJ.0000014451.99047.69.

[26] ROTHGANG, M., TRETTIN, L. Strengthening the German Craft sector through Innovation and Cooperation. In: ERSA conference papers (No. ersa03p52). European Regional Science Association, 2003.

[27] SAFIN, K. Managing small enterprise. Wroclaw: Akademia Ekonomiczna, 2003. ISBN 83-7011-646-9.

[28] ŠIPIKAL, M., PISÁR, P., URAMOVÁ, M. Support of innovation at regional level. $E+M$ Ekonomie a Management. 2010, Vol. 13, Iss. 4, pp. 74-84. ISSN 1212-3609.

[29] TETHER, B.S. Who co-operates for innovation, and why: an empirical analysis. Research policy. 2002, Vol. 31, Iss. 6. pp. 947967. ISSN 0048-7333. DOI: 10.1016/S00487333(01)00172-X.

[30] TORRES, A.M. Marketing networks as a form of strategic alliance among craft enterprises. International Journal of Nonprofit and Voluntary Sector Marketing. 2002, Vol. 7, Iss. 3, pp. 229-243. ISSN 1479-103X. DOI: 10.1002/nvsm.182.
[31] WAGA, M. Financing sources for small and medium enterprise activities in respect of their financial situation. Studia Biura Analiz Sejmowych kancelarii sejmu. Development of entrepreneurship and small and medium-sized enterprises. 2014, Vol. 1, Iss. 37 [cit. 2014-12-29], pp. 27-47. Available from: http://orka.sejm.gov.pl/WydBAS.nsf/0/ B84674677D84FDF2C1257CA20043551F/ \$file/Studia_BAS_37.pdf. ISSN 2082-0658.

[32] ZENG, S.X., XIE, X.M., TAM, C.M. Relationship between cooperation networks and innovation performance of SMEs. Technovation. 2010, Vol. 30, Iss. 3, pp. 181-194. ISSN 0166-4972. DOI: 10.1016/j. technovation.2009.08.003.

Prof. Joachim Foltys, Ph.D. Eng. Opole University of Technology Faculty of Economy and Management Department of Organization and Business Management j.foltys@po.opole.pl

Grażyna Dębicka-Ozorkiewicz, Ph.D. Chamber of Crafts in Opole grazyna.debicka@izbarzem.opole.pl

Jolanta B. Królczyk, Ph.D. Eng Opole University of Technology Faculty of Production Engineering and Logistics

Department of Biosystems Engineering j.krolczyk@po.opole.pl

doc. Ing. Vladimír Hiadlovský, PhD. Matej Bel University Banska Bystrica Faculty of Economics Department of Corporate Economics and Management vladimir.hiadlovsky@umb.sk 


\title{
Abstract
}

\section{FINANCING CRAFT ENTERPRISES ASSOCIATED IN THE POLISH CRAFT ASSOCIATION}

\author{
Joachim Foltys, Grażyna Dębicka-Ozorkiewicz, Jolanta B. Królczyk, \\ Vladimír Hiadlovský
}

This article concerns functioning of small and medium enterprises and in particular: craft ones. In the sector structured European Union, the abovementioned stand for $80-95 \%$ of the existing companies and moreover, they generate the biggest number of job positions and the national income. The article focuses on a selected part of SME sector: craft enterprises and especially, on financing their activities. This financing relates to both, financing craft businesses' investments and their current operations. In the first part of the text one presents a literary query concerning the definition of a craft enterprise and the resulting from its characteristic functioning: conception and tools for financing investments and current operations of craft enterprises. In the second part, one demonstrates the results of researches on the conception and the tools for financing craft enterprises functioning on the Polish market. In the summary of the article one demonstrates conclusions concerning the ways of maintenance and (in many cases innovative) changes of the conception and the tools for financing craft enterprises. The element congruous with the basic topic of the article relating to the current functioning of a craft enterprise in the real environment (both: inner and outer one), is its functioning in the digital surrounding (including with regard to the conception of financing activities), which correlates with the dynamic development of ICT technologies. The aforementioned development together with digitalization determines many aspects of craft enterprises' functioning; also the ones connected with financing tools and conceptions. Referring to the things stated, it is clear that ICT technologies should be taken into account in enterprise's current activities and in other aspects of its functioning e.g. communication, as well as eservices it provides and receives.

Key Words: SME sector, craft enterprise, financing, financing tools, management methods, financial engineering, outsourcing, virtual space.

JEL Classification: G2, G3.

DOI: 10.15240/tul/001/2015-4-012 